Kong. Res. J. 4(1) : 48-52, 2017

ISSN 2349-2694

Kongunadu Arts and Science College, Coimbatore.

\title{
NATURE AND SOCIETY AS REFLECTED IN ACHEBE'S THINGS FALL APART
}

\author{
Dhanalakshmi, T. \\ Department of English, Tirupur Kumaran College for Women, Tirupur. \\ Email: kavigobinathbabl@gmail.com
}

\begin{abstract}
The aim of this paper is to attempt a reading of Things Fall Apart from an eco-critical perspective to show that Achebe was writing the novel in part to make his African readers aware of the extent of the embeddedness of their forefathers in the environment. To illustrate the ways through which he delineates the manifold connections between the African and the land. Achebe intends to focus on his depiction of the damage caused in the relationship between Africans and their natural world by the advent of colonization. Finally, through this paper hope to emphasize Achebe's profound belief in the importance of the connections Africans must reactivate with nature to make themselves whole again.
\end{abstract}

Keywords: Chinua Achebe, Ecocriticism, Things Fall Apart.

Eco-criticism has been glossed as "the study of the relationship between literature and the physical environment" Eco-criticism as something that "implies the long-term imbrication of humans in a landscape of ancestry, and death, of ritual, life and work" (108)1 Dwelling, for Gerard, involves the nexus between the lived life of a community and its rituals, between the human and the inhuman, between nature and culture. In building dwellings, a community roots itself in the physical world, and that world becomes a locus of memory and desire, till the land takes on a "figural" as well as a "literal" value (115).

Things Fall Apart is to represent the intimate relations West Africans had with the natural world before things started to "fall apart" from them as a consequence of colonization. What is distinctive about the novel is the manner in which it shows the close links between the Igbo people and their physical environment.

Things Fall Apart is not only the story of Okonkwo, a headstrong and proud man who is forced to commit suicide after being humiliated by the white men, it is also the story of the African community of Umuofia to which he belongs and its changing fortunes because of the coming of Europeans. What one notices about the first twothirds of the novel is how Okonkwo's story is embedded in that of his community. It is interesting to read that Okonkwo's father Unoka lived in perfect harmony with his people and the land, while Oknokwo himself had a troubled relationship with it. In the eyes of the son Unoka is a failure, but we come to like him despite his son's complexes about his father, because "he loved the season of the year, when the rains had stopped and the sun rose every morning with dazzling beauty" (Achebe, Things, 4). For sure, he and the villagers are also aware of the darker aspects of nature, but they have learned to balance apprehension of dark nights with enjoyment of moonlit ones, knowing what to avoid and what to take pleasure in. They key to survival was to realize as the clan does when the rainy season overwhelms them that "nature was not interfered with" (31).

Unoka's death is indicative of the balance and good sense the community has achieved in rooting itself in the land, for when he is afflicted by a swelling of his body parts, the people of the village take him to the Evil Forest and leave him to die in isolation, no doubt because it knew that someone with contagious diseases such as small pox or leprosy or a virulent infection was best isolated from others. People who respected the earth and satisfied its yearnings. This is why when the characteristically intemperate Okonkwo beats up his wife, Ezeani, the priest of the earth goddess, Ani, rebukes him saying, "Our forefathers ordained that before we plant any crops in the earth we should observe a week in which a man does not say a harsh word to his neighbor as: "We live in peace with our fellows to honour our great goddess of the earth without whose blessing our crops will not grow" (28). But even Okonkwo knows that the earth goddess had to be appeased since she was "the source of all fertility" (33). That is why he mostly succeeds in life and ends up becoming a powerful and rich member of the community despite starting as a simple sharecropper. It is only when he exceeds the limits set on men, as when he kills the boy Ikemefuna with 
his own hands needlessly although the child was in his care that he is criticized by members of his community for doing something unnatural.

In the second part of Things Fall Apart, Okonkwo is exiled from Umuofia because he has accidentally killed a member of the community, but this is due to his bad luck or the workings of his chi or personal god than to a personal failing. Interestingly, fratricide too is seen as "a crime against the earth goddess" (113), accidental or not, and Okonkwo has to settle with his mother's clan in the village of Mbanta for seven years. Here again his capacity for hard work means that he will be eventually rewarded by the earth and he will be able to rebuild his life in the new community. It is during his period of exile in Mbanta that Okonkwo first hears of the coming of the white man on "an iron horse" (125), as ominous to the villagers as the locusts that periodically afflict the land. Soon the whites bring their religion and win over outcasts and people like Okonkwo's son Nwoye, who had been alienated from his father's harsh ways ever since the murder of Ikemefuna. Significantly, one of these outcasts kill "the most reverend animal in Mbanta and all the surrounding clans" (145) the python, and in doing so infuriates the Ibos, particularly Okonkwo.

Okonkwo before he returns to Umuofia at the end of seven years, he has found out that the white men's religion as well as government had spread over the land and converted many dissatisfied Igbo like Nwoye. The coming of the white man on an iron horse and the destruction of the royal python are symptomatic of the problems caused by the strangers. Although Mr. Brown, the first white missionary, seems conciliatory and preaches the form of Christianity appeals to mildmannered men such as Nwoye, the Umuofians have split because of them and have become vulnerable. Part Two of the novel thus ends with one of the oldest members of the community talking about 'an abominable religion' that had divided the Igbos (152), causing some of them to abandon their people. He is fearful about Okonkwo's future and that of the clan; he can see the beginning of the end of their way of life.

Part Three of the novel finds Okoknwo back among his people in Umuofia, but it now contains a court house and a prison where the white men incarcerate anyone who offends them or transgresses their laws. As his friend Obierika tells him about the whites have "put a knife on the things that held us together and we have fallen apart" (160). Things become worse when the accommodating $\mathrm{Mr}$. Brown is replaced by the aggressive Reverend James Smith. With his encouragement, Enoch, the turncoat slayer of the royal python, kills an ancestral spirit till "Umuofia is thrown into confusion" and the land seems to be full of "a strange and fearful sound" (168). The connections between the land and the community has come under severe strain and "the eerie voices of countless spirits" (169), disturbed and militant, raid Mr. Smith's church to flush out Enoch and then burn it. To the enraged Umuofians, the church and people like Mr. Smith and their lackeys among the converts had "bred untold abominations" (171). For the white invaders, the destruction of the church is the last straw. The white District Commissioner captures the Umuofian Okonkwo and the other men responsible for the attack and humiliates them. His court messengers then broadcast through the land his decision to release them only after a hefty fine had been paid by the clan for them.

Through a whole series of negative constructions Achebe portrays the dark and depressing shadow that has benighted the land, straining its people till they are on the verge of collapse: It was the time of the full moon. But that night the voice of children was not heard. The village ilo where they always gathered for a moon-play was empty. The women of Iguedo did not meet in the secret enclosure to learn a new dance to be displayed later to the village. Young men who were always abroad in the moonlight kept their huts that night. Their manly voices were not heard on the village paths as they went to visit their friends and lovers. Umuofia was like a startled animal with ears erect, sniffing the silent, ominous air and not knowing which way to run (176-77). The sense of oneness with nature, the sense of a dwelling, of an environment where one feels at home is gone; the harmony and balance that sustained the community have disappeared; and the traumatized villagers have lost their sense of place and consequently have no sense of direction anymore. The villagers collect the money needed to release the captives. But when they meet again to decide on how best to drive the strangers out, court messengers appear on the scene to disrupt the meeting. It is at this point that Okonkwo slays one of them. Realizing that he would be hanged publicly for his action, Okonkwo kills himself, committing in the process the ultimate abomination, for a man who takes his own life, will therefore not be buried by his own people and would end up buried like a dog.

Things Fall Apart thus ends with the Umuofians traumatized, one of their standard 
bearers destroyed, and the land itself degraded. And yet the novel had begun with a country where Ani, the earth, cared compassionately over the Igbos. Together with Agbala, the Oracle of the Hills and the Caves, and through their priests and priestesses, they had once upon a time ensured that mystic unity and eternal order over the universe. Though there were strains in the community these were contained in complex and manifold ways. But Achebe leaves us with no doubt that no matter how severe and proud a man Okonkwo was, and no matter how rigid the society in which he lived could be, the catalyst that destroys the fabric of the community and upsets the balance that sustained it is the coming of the white man. As the African critic Abiola Irele states it: Achebe's novels "deal with the social and psychological conflicts created by the incursion of the white man and his culture into the hitherto selfcontained world of African society, and the disarray in the African consciousness that has followed" (80).

Achebe himself, as he put it in an interview, it is his belief that the European invasion resulted in Africans losing their "grip over history". It also led to their losing their memory of Africa, a massive loss since the past is all we have. That is why he had endeavored to tell the story of Okonkwo and Umuofia's destruction, for the story of their strengths and weaknesses must be told as effectively as possible if the people of Nigeria were to achieve some sort of balance again. To tell the story of the falling apart of the Umuofians, Achebe resorts to the storytelling techniques and traditions of his people. When in an interview with Charles H. Rowell, he is asked what he means by identifying himself as a storyteller, this is what he has to say: ..."we mustn't forget that we have a certain link of apostolic succession; if you like, to the old griots and storytellers and poets. It helps anyway; it gives me that sense of connectedness, of being part of things that are eternal like the rivers, the mountains, and the sky..."(Rowell, 269). This sense of connectedness and of being in the tradition of oral story-telling is most clearly manifested in Achebe's use of Igbo proverbs and his use of metaphors and similes that arise from the African story-teller's oneness with the physical environment.

In Things Fall Apart, the narrator signals the centrality of proverbs rooted in nature in the opening pages of his narrative when he tells us: "Among the Ibos the art of conversation is regarded very highly, and proverbs are the palm oil with Chinua Achebe's Things Fall Apart Eco-critically which words are eaten" (6). The story of Okonkwo's rise and fall and of his community's disintegration is thus strung with proverbs. For instance, Okonkwo on the rise is admired for his wily qualities which are said to make him "as slippery as a fish in water" (3). His physical prowess makes him highly visible in Umuofia where his fame is said to have grown "like a bush-fire in the harmattan" (ibid). He is accepted by the elders of the community, one of whom graciously accepts his present of kola nut and alligator pepper. The elder acknowledges his status and right to be himself by telling him, "Let the kite perch and let the egret perch too" (17-18). In fact, this elder helps Okonkwo consolidate his presence in the community since he is convinced that "you can tell a ripe corn by its look" (20). For the narrator, nature is the source of the most vivid comparisons. Ikemefuna, the child Okonkwo had adopted, is said to have been growing in his household "like a yam tendril in the rainy season" (47). When Okonkwo's favorite daughter Ekwefi is frightened, the narrator tells us that she is "like a hen whose only chick has been carried away by a kite" (93). When her fear becomes that of the community, the narrator notices fireflies going around "with their tiny green lamps, which only made the darkness more profound" (94).

Achebe makes it quite clear that for the story-teller of a people who live in harmony with the land, nature is the source of all the figures of speech necessary for their story-telling. In Chapter 11 of the novel we have a story-telling episode where Ekwefi, another of Okonkwo's wives, narrates the story of a tortoise and birds to her daughter Ezinma. When she finishes her story Ezinma herself begins to narrate another story; this time one about a tortoise and cats. Noticeably, everything ends up as a story. In the stories of the clan, nature plays an integral part and often provides the characters as well as the metaphors. Thus when towards the end of the narrative the humiliated clan men try to organize and put up resistance against the invaders, the strategy they are asked to adopt is compared to the one that Eneke the bird used "to fly without perching like a twig" (183). It is significant that the proverbs and the metaphors of the first part of the story begin to disappear as the whites make their presence felt in Umuofia. The proverbs that replace them are often from the tradition of the white colonizers. In one obviously ironical instance, we learn that Mr. Smith punished a woman who had converted to Christianity "for pouring new wine into old bottles" (166). But the more repugnant Mr. Brown seems to see only through a reductive perspective based on the principle of puritan allegory where "the world was a battlefield in which the children of light were 
locked in mortal conflict with the sons of darkness" (166).

The district commissioner for his part uses an animal metaphor, but there is obvious irony in his telling the clan men that if they played "any monkey tricks they would be shot" (186). The one noteworthy metaphor associated with the clan in the concluding chapters is, one that is from everyday experience that has become folk wisdom, for one of the elders talk about their predicament as comparable "to a toad jumping in broad daylight" (182), a sure sign of desperation. To the Umuofians nature in its bounty provide them with endless images with which they can weave their proverbs, metaphors and stories. To the whites the native mode of speech seems wasteful and decorative. This, at least, is what goes through the irate District Commissioner's mind when he is trying to find out where Okonkwo has disappeared, for he thinks then: "one of the most infuriating habits of these people was their love of superfluous words" (185). At this level, Things Fall Apart dramatizes what the critic Ato Quayson has called " the struggle between an organic esthetic...indigenous to the culture and an esthetic...that comes with colonialism" (833). Overwhelmed by the whites, the proverbs and the metaphors of the Igbos seem to suffer like the people themselves. No doubt because the district commissioner is intent on straightening out the language and the narratives of these people as well as their politics, he resolves to title his account of his experience in the region, "The Pacification of the Primitive Tribes of Lower Niger" (Achebe, Things, 187). But Achebe himself takes the opposite tack in writing his tale of the way things fell apart for his country. His mission was to bring the land and its stories alive by using a vibrant narrative strategy dependent on indigenous story-telling traditions and techniques. As he puts it in his famous essay, “Colonialist Criticism': "every literature must seek the things that belong unto its peace, must, in other words, speak of a particular place, evolve out of the necessities of its history, past and current, and the aspirations and destiny of its people" (Achebe, Hopes, 74).

Chinua Achebe's Things Fall Apart has indicated that he has presented through his novel a West African world whose inhabitants had bonded with their physical surroundings, learning to live in it, respect, and get sustenance from it. They had made their landscape a place where memory, work, cultural practice, and rituals had intermingled, creating a balance in their lives that made life meaningful for them. People had become one with place and culture and nature had merged for the Igbo. Achebe, tried to show, had drawn inspiration from his remembrance of a time when his people had adjusted themselves to their environment and felt that there was something from it that presentday Africans would learn from. He had, it can be said, been inspired by his ecological consciousness to write his narrative of Umuofia and its inhabitants. Wendell Berry, a major American poet and advocate of the environment movement has observed that: "A human community... must collect leaves and stories, and turn them to account. It must build soil, and build that memory of Chinua Achebe's Things Fall Apart Eco-critically itself" (Garard, 115) and it is part of Achebe's achievement to have done so in his novel. But Achebe's success as a novelist in Things Fall Apart is also to show how the coming of imperialism had impacted adversely on the lives of people who had been dwelling in harmony with nature and how the coming of the whites had disturbed the balance achieved by the West Africans in their dealings with their environment.

Achebe through his narrative strategy, his use of time, and his mastery of language and deployment of proverbs and metaphors, he has succeeded in depicting the manner in which the community became troubled and the land became polluted by the advent of colonization. By the time he concludes the novel we come to realize that the Igbo world had become traumatized and the complex ties forged between nature and society by the clan had become unsettled because of the actions of men like Mr. Brown and the District Commissioner. This paper has attempted an eco-critical reading of Achebe's great novel to show how he wrote it from what would now be called an ecological consciousness to suggest that Africans learn to value the land that they dwell in and to point at the importance of respecting the natural world. Achebe wrote Things Fall Apart, of course before the discipline called Eco-criticism was born.

Ursula K. Heise, an American proponent of Eco-criticism, has defined the parameters of the subject thus: 'Eco-criticism analyzes the ways in which literature represents the human relations to nature at particular moments of history, what values are assigned to nature and why, and how perceptions of the natural shape literary tropes and genres" (1097). Hopefully, this reading of Things Fall Apart has shown that Eco-criticism as a subject has a lot to offer us as we attempt to offer new readings of the texts emanating from our part of the world. 


\section{REFERENCES}

Achebe and Chinua, 1994. Things Fall Apart, New York Anchor Books.

Huggan, Graham, 2004. Greeting Post Colonialism: Eco- Critical Perspectives. Modern Fiction Stud. 50(3): 701-733.
Buell, Larance, 2001. Eco criticism:Some Emerging Trends. Qui Parle: Critical Humanities and Social Sciences 19(2): 87-115.

Glofelty, Cheryll, 1996. Introduction. The EcoCriticism Reader. Landmarks in Literary Ecology.Ed.Cheryll Glotfelty and Harold From USA, University of Georgia Press XV-XXXVii. 